\title{
Youth Digital Hub Modelling in Promoting ICT Knowledge Sharing and its Application among Youth Community of Practice
}

\author{
Rusli Abdullah, Abdifatah Farah Ali
}

To Link this Article: http://dx.doi.org/10.6007/IJARBSS/v11-i17/11415

DOI:10.6007/IJARBSS/v11-i17/11415

Received: 07 August 2021, Revised: 30 August 2021, Accepted: 23 September 2021

Published Online: 11 October 2021

In-Text Citation: (Abdullah \& Ali, 2021)

To Cite this Article: Abdullah, R., \& Ali, A. F. (2021). Youth Digital Hub Modelling in Promoting ICT Knowledge Sharing and its Application among Youth Community of Practice. International Journal of Academic Research in Business and Social Sciences, 11(17), 277-284.

Copyright: (C) 2021 The Author(s)

Published by Human Resource Management Academic Research Society (www.hrmars.com)

This article is published under the Creative Commons Attribution (CC BY 4.0) license. Anyone may reproduce, distribute, translate and create derivative works of this article (for both commercial and non-commercial purposes), subject to full attribution to the original publication and authors. The full terms of this license may be seen

at: http://creativecommons.org/licences/by/4.0/legalcode

Special Issue Title: Empowering Community and Beyond, iRandau, 2021, Pg. 277 - 284

Full Terms \& Conditions of access and use can be found at http://hrmars.com/index.php/pages/detail/publication-ethics 


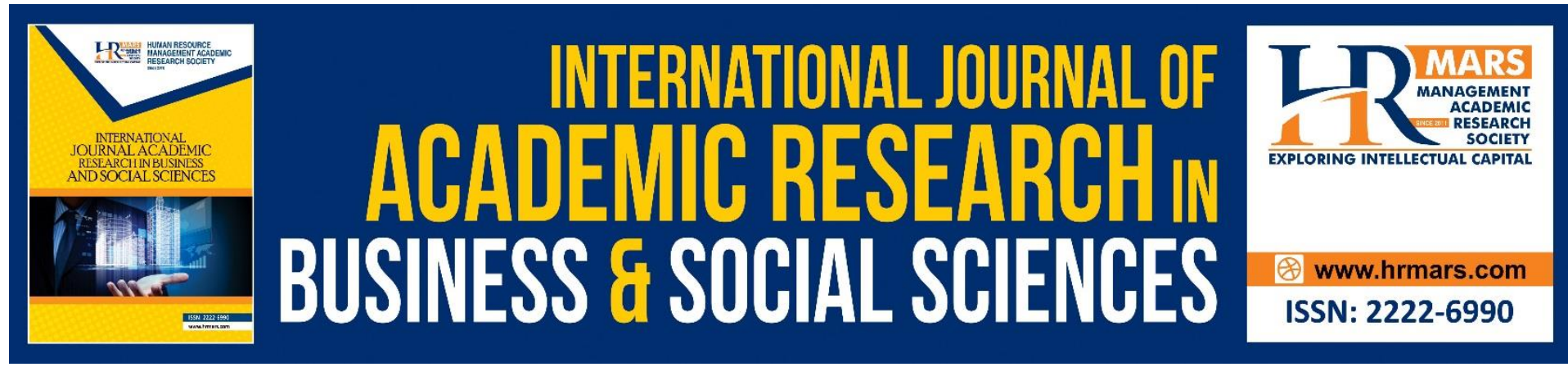

\title{
Youth Digital Hub Modelling in Promoting ICT Knowledge Sharing and its Application among Youth Community of Practice
}

\author{
Rusli Abdullah ${ }^{1,2}$, Abdifatah Farah $\mathrm{Ali}^{3}$ \\ ${ }^{1}$ Faculty of Computer Science and Information Technology, Universiti Putra Malaysia, \\ Serdang, Malaysia, ${ }^{2}$ Research Associate at IPSAS, Universiti Putra Malaysia, Serdang, \\ Selangor, Malaysia, ${ }^{3}$ SIMAD University, Mogadishu, Somalia \\ Email: rusli@upm.edu.my
}

\begin{abstract}
Youth and information communication of technology (ICT) are two concepts that work together and related to each other right now especially in supporting the knowledge sharing and its application of youth community of practice (YCoP). Those concepts can be extended in term of how the youth as a community of practice can make use of the ICT knowledge as a platform for the best of their future purposes for themselves. However, some of the members of the youth community are still not aware on the method to ensure that the ICT can be shared and applied by them as much as possible to improve their work entirely. Therefore, by proposing the model of youth digital hub (YDH), it can motivate the members of YCoP to use the model as a guideline in ensuring that they can utilize the ICT for any purposes of their life efficiently and effectively.
\end{abstract}

Keywords: Application System, Information System, Youth Digital Hub, Youth Community of Practice, Information Communication Technology

\section{Introduction}

Manuscripts Youth and information communication of technology (ICT) are the concepts that are working together and related to each other especially in supporting the youth community of practice (YCoP) (Markantoni et al., 2019). Those concepts can be extended in term of how the youth as a community of practice can make use of the ICT as a platform for the best of their future purposes digitally (Unicef, 2014). However, some of the members of the youth community are still not aware on the method to ensure that the ICT can be shared and applied by them as much as possible to improve their work entirely. Therefore, by proposing the model of youth digital hub, it can motivate the members of YCoP to use the model as a guideline in ensuring that they can utilize the ICT for any purposes of their life efficiently and effectively.

In this paper, youth digital hub (YDH) concept and its definition will be presented in Section 1 as an introduction, and then the relationship of YCoP and ICT based on literature review will be described comprehensively in Section 2. This will be followed by Section 3 which is about research methodology in describing how the research problem based on YDH proposal is 
related to transform the research problems into research solution. Furthermore, Section 4 is about the initial of YDH modelling formulation and its discussion as the research outcome of YDH Modelling based on the expert opinion who are involved in youth activities with ICT environment actively.

\section{Literature Review}

For the literature review (LR) purpose, the explanation will begin with the discussion on youth definition especially in the context of Malaysia environment and how it is related to ICT technology or application in supporting of knowledge sharing for the youth development environment. The details of the discussion on this relationship are highlighted as follows:

\section{The Youth in Malaysia Environment}

It is defined for the people aged $15-40$ years based on National Youth Development Policy. It was then later revised back in 2011 where the youth is redefined for those who are in the age of 18-25 years especially in working collaborative among Youth Community of Practice (YCOP) (Unicef, 2014).

\section{Relationship between the Youth and ICT application}

The relationship between the youth and ICT can be viewed in terms of how ICT can be used especially in online manner and its digital context (Cullen, 2002). The role of ICT for youth also can be viewed as ICT technological solution for their purposes in terms of computer hardware which is in the form of electronic gadget (Doyle, 2020; PMO Office, 2021).

On the other hand, the software is related to any kind of applications or apps that is used or applied together with the gadgets or computer hardware. In relation to promoting the knowledge sharing among the YCoP based on the ICT application or environment, the skill set of YCoP can be categorized into three major applications (Geissdoerfer et al, 2018; London et al, 2010). The details of these technologies and their respective application-based on their skill set requirements are highlighted as follows:

- Youth and their gadgets as a platform or device that is used by member of YCoP to initiate businesses for their quality of life (Ali \& Miller, 2017; Priya Pedamkar, 2021; Zavratnik et al, 2018).

- Personal or Desktop Computer

- $\quad$ Servers

- Notebook

- Laptop

- Handphone or iPhone or Smartphone

- iPad

- $\quad$ PS2 and PS4 devices

- $\quad$ Software and their essential applications in supporting YCoP to create and manipulate documentation digitally and graphically (Indeed Editorial Team, 2020)

- Word Processing Application

- Database Management System

- $\quad$ Graphical User Interface of Authoring System

- Design and Coding of Application System

- Internet and its Cloud-based System (CbSys) as an alternative technological solution in helping YCoP as a service (XaaS) for them to work together collaboratively among 
themselves electronically or digitally (Rundel et al., 2020; Jemistry, 2021).

- E-Commerce System - Related to the transaction of commercialization between customer and business (C2B), business to business (B2B), customer to customer (C2C).

- $\quad$ E-banking System - Related to the transaction of banking system between customer of youth and banker environment.

- $\quad$ E-learning System - Related to the transaction of teaching and learning (T\&L) between student or youth and the teacher or lecturer.

- $\quad$ E-Government System - Related to the transaction of administration between customer of youth and government entities like youth department and many others.

- $\quad$ E-Healthcare System - Related to the patient of treatment between youth and doctor and pharmacist for their healthcare environment.

- E-Games - Related to the transaction of sport management and its activities between members of YCoP environment.

As a summary, these three of technological aspects as what is highlighted in Section 2.2, it is being considered or identified as point of departure of towards YDH formulation for knowledge sharing purposes of their YCoP to work together successfully.

\section{Research Methodology}

As a starting point in proposing the model of $\mathrm{YDH}$, we are conducting a preliminary study by using the secondary data based on the literature review especially in relation to ICT for youth and their application and skill sets required by youth community of practice (YCoP). There are five expert opinions used to verify the proposed model based on their knowledge of ICT practitioners about the YCoP as well as to get the agreement of the functional requirement on the YDH model proposal. The selection of this expertise is also based on their involvement in youth business activities actively (Carroll etal.,1972; Boudreau, Gefen \& Straub,2001) . Lastly, the data collection is performed based on LR as well as the expert opinion or perceptions that have been analysed for verification process in formulating and proposing the YDH model which is related to the major component as well as its sub-components.

\section{A proposed model of Youth Digital Hub to support Youth Development Environment for their activities.}

The Youth Digital Hub (YDH) model proposal is consisting of four parts or components of technological skill as shown in Figure 1. The first component is related to personal, or desktop technological skill set. The second component describes the management technological skill. The third component is related to technological skill set that allows youth to work professionally. Finally, the fourth component is something that is related to social technological skill set like application for enhancing knowledge and other related business. 


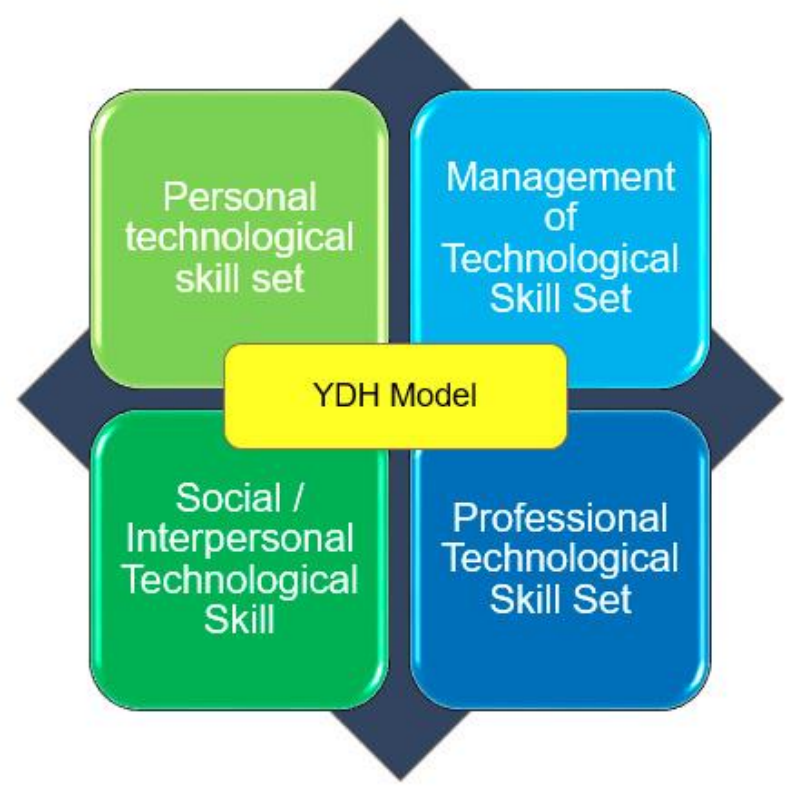

Figure 1: A proposed of YDH modelling

\section{Part 1- Personal technological skill set}

This is the technological skill set that is related to personal development of youth in enhancing their skill for the purpose of self-development. This includes the skill in:

- $\quad$ operating system and its related devices or platform such Window, Android, and IOS,

- $\quad$ desktop publishing tool

- $\quad$ Other application development tools.

\section{Part 2- Management of Technological Skill Set}

This is related to youth abilities in managing their technological skill set for the purpose of data collection, data analysis and data interpretation as well as data presentation. The other aspect of management of technological skill of youth is related to:

- data management system

- data manipulation and prediction

- data visualization.

The most related example of technological skill is Database Management System like MS Access.

\section{Part 3- Social/Interpersonal Technological Skill Set}

This is the social or interpersonal technological skill set that is related to communication skill of technologies such as social media and e-mailing system. This includes technological skill set in handling:

- Communication (synchronously and asynchronously),

- $\quad$ Negotiation (win-win situation),

- $\quad$ collaboration in working together that can be happen in real time or other time like online or offline mode of operation environment. 


\section{Part 4- Professional Technological Skill Set}

Professional technological skill set is related to developing youth in enhancing their skill professionally. This is including the skill in business or enterprises system and its related area such as:

- $\quad$ accounting system,

- $\quad$ marketing system,

- $\quad$ human resources management system for the purposes of decision making etc.

\section{Result and Discussion}

In the context of the YDH modelling, there are four parts of the modelling identified that are very important to support YCOP as an outcome of the LR as well as the verification process that has been performed based on the expert opinion and their agreement as shown in Figure

2.

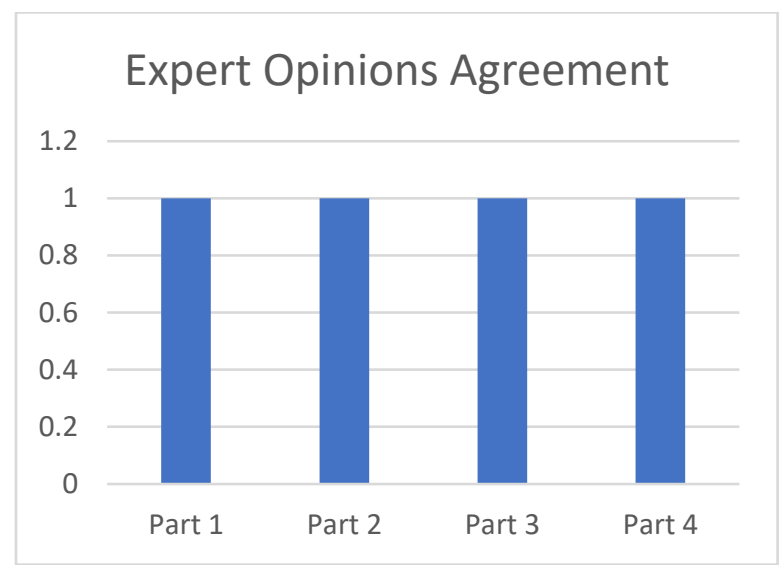

Figure 2: A proposed of YDH modelling and Expert Agreements in supporting YCoP.

Besides that, the experts also agreed that the emphasize is required to be placed to the items of each sub-components as what have been proposed for the benefits of YCoP in working their tasks efficiently and effectively. The skills requirement for the purpose of YCoP are highlighted as a YDH modelling which consists of components and its sub-components as shown in Figure 3 and Figure 4 respectively.

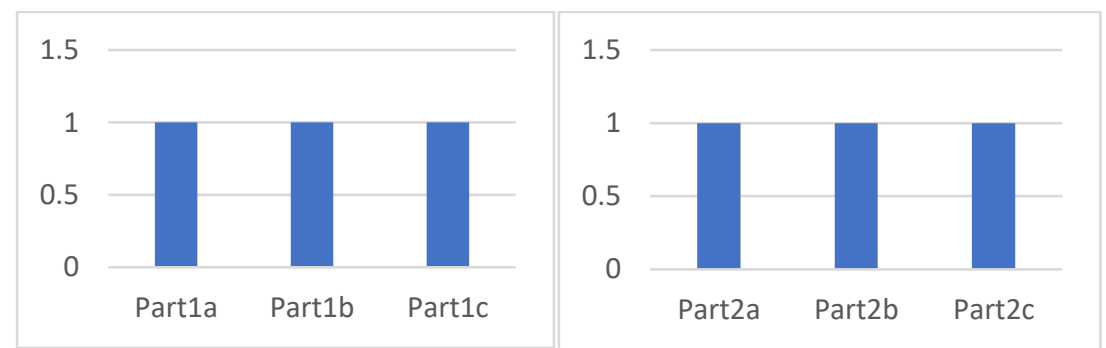

Figure 3: Expert agreement of YDH Model and its Personal technological (Part1a, Part1b, Part1c) and Management of Technological (Part2a, Part2b, Part2c) skill of in supporting YCOP 


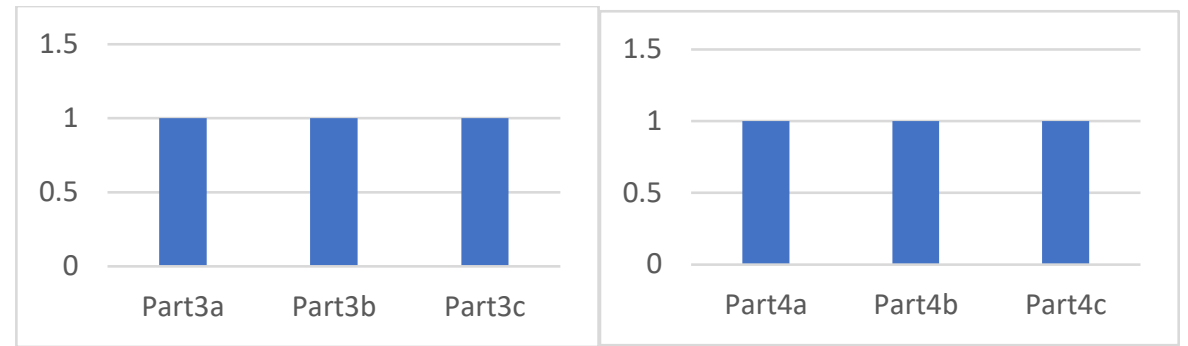

Figure 4: Expert agreement of YDH Model and its Social/Interpersonal Technological (Part3a,

Part3b, Part3c) and Professional Technological (Part4a, Part4b, Part4c) skill set of in supporting YCoP

\section{Conclusion and Future Work}

As we know, youth and information communication of technology (ICT) are related to each other and working together especially in supporting the youth community of practice (YCOP) for accomplishing their purposes. Those concepts can be extended in terms of how the YCoP can fully utilized the ICT as a platform for the best of their future purposes. Some of the members of YCoP are still not aware on the method to ensure the ICT can be contributed to them as much as possible to improve their work entirely. As a result, by using the proposed model of youth digital hub (YDH), it can motivate the members of YCoP to have a better life efficiently and effectively. As a future work, the proposed model will be tested again on the YCoP in getting their agreement as well as to verify the usability of the conceptual design of YDH model as a prototyping system.

\section{References}

Ali, M., \& Miller, L. (2017), ERP system implementation in large enterprises - A systematic literature review. J. Enterp. Inf. Manag., 30, 666-692.

Boudreau, M. C., Gefen, D., \& Straub, D. W. (2001). Validation in Information Systems Research: A State-of-the-Art Assessment. MIS Quarterly, 25(1), 1-16.

Carroll, S. J., Paine, F. T., \& Ivancevich, J. J. (1972). The relative effectiveness of training methods: Expert opinion and research. Personnel Psychology, 25(3), 495https://doi.org/10.1111/j.1744-6570.1972.tb00833.x

Cullen, R. (2002). Addressing the digital divide. Online Information Review. Vol. 25 (5): 311-320.

Doyle, A. (2020), Important Computer Skills for Workplace Success, https://www.thebalancecareers.com/computer-skills-list-2063738. Access at Jan 2020.

Geissdoerfer, M., Morioka, S.N., de Carvalho, M. M., \& Evans, S. (2018), Business models and supply chains for the circular economy. J. Clean. Prod, 190, 712-721.

Indeed Editorial Team. (2020), Technical Skills: Definitions and Examples https://www.indeed.com/career-advice/resumes-cover-letters/technical-skills. Access at Jan 2020.

Jemistry. (2021), Jemistry.com,cloud-system-applications.https://www.jemistry.com/cloudsystem applications. Access at June 2021.

London, R. A., Pastor, M., Jr., Servon, L. J., Rosner, R., \& Wallace, A. (2010). The role of community technology centers in promoting youth development. Youth \& Society, 42(2), 199-228. https://doi.org/10.1177/0044118X09351278 
Markantoni, M., Steiner, A. A., \& Meador, J. E. (2019). Can community interventions change resilience? Fostering perceptions of individual and community resilience in rural places. Community Development, 50(2), 238- 255. https://doi.org/10.1080/15575330.2018.1563555

PMO Office. (2021), Malaysia Digital Economy Blueprint, https://mdec.my/wpcontent/uploads/MDEB_ENG_FINAL-compressed.pdf. Access at June 2021.

Priya Pedamkar. (2021), What is Application Software \& Its Types https://www.educba.com/what-is-application-software-its-types/. Access at June 2021.

Unicef. (2014), Exploring the Digital Landscape in Malaysia. Unicef Malaysia.

Rundel, C., Salemink, K., \& Strijker, D. (2020). Exploring rural digital hubs and their possible contribution to communities in Europe. The Journal of Rural and Community Development, 15(3), 21-44.

Zavratnik, V., Kos, A., \& Duh, E. S. (2018). Smart villages: Comprehensive review of initiatives and practices. Sustainability, 10(7). https://doi.org/10.3390/su10072559 